\title{
Genetic Analysis for Quantitative and Quality Characters in Three Single Crosses of Upland Cotton
}

\author{
Srinivasan KANNAN ${ }^{1}$, Rajashekaran RAVIKESAVAN² ${ }^{2}$, Mahalingam GOVINDARAj* \\ ${ }^{1}$ Cotton Breeder, Rasi Seeds Private Ltd, Attur, Salem - 636 102, Tamil Nadu, India \\ ${ }^{2}$ Tamil Nadu Agricultural University, Centre for Plant Breeding and Genetics, Coimbatore- \\ 641 003, India; mahagovind@gmail.com ( ${ }^{*}$ correspondingauthor)
}

\begin{abstract}
Gene effects were studied for 12 characters in three crosses of Gossypium hirsutum by six generation mean model to determine the potential for improvement of yield components and fiber quality in upland cotton. Additive genetic variance (gene action) was predominantly operating in the inheritance of boll weight, single plant yield, and lint index. In the presence of epistasis dominance and additive $\times$ additive gene effects were observed for boll weight, single plant yield, lint index, ginning outturn, 2.5 percent span length, bundle strength fineness and uniformity ratio. Boll weight, lint index, seed index, ginning outturn, fineness, bundle strength and uniformity ratio were predominantly under the control of dominance and dominance $x$ dominance gene action. Duplicate type epistasis was noticed for all the studied characters and the possible breeding strategies for improvement of lint yield and quality traits were discussed.
\end{abstract}

Keywords: fibre quality, gene effects, generation mean model

\section{Introduction}

Cotton (Gossypium hirsutum) is one of the important commercial crops of world and it is considered as the 'King' of fibers. India ranks number one in the world accounting for $33 \%$ of the total area planted under cotton. However, even with highest area under cotton, 10.7 million hectares, India ranks second with $22 \%$ of world production (AICCIP Report, 2010-2011). India's average lint yield is only $496 \mathrm{~kg} / \mathrm{ha}$ as compared to world average of $748 \mathrm{~kg} / \mathrm{ha}$ (AICCIP Report, 2010-2011). In addition to lint yield, fiber quality is foremost apparent for high market price. Cotton fiber quality is defined by its physical properties that relate to the spinnability into yarn and textile performance (Chee et al., 2005a). The most important of these properties are those associated with the length, strength and fineness/ micronaire of the fiber (Poehlman and Sleper, 1995). Other components of cotton fiber quality include length uniformity index, elongation, color as reflectance $(\mathrm{Rd})$ and yellowness $(+\mathrm{b})$. The naturally wide variations in fiber quality, in combination with differences in end-use requirements, result in significant variability in the value of cotton lint to the processor. Therefore, a system of premiums and discounts has been established to denote a specified base quality. In general, cotton fiber value increases as bulk-averaged fibers increase in whiteness (Rd), length, strength, and discounts are made for both low and high mike. Ideal fiber-quality specifications favored by processors traditionally have been summarized, "as white as snow, as long as wool, as strong as steel and as fine as silk." These specifications are extremely difficult but important to incorporate into a breeding program or to set as goals for cotton producers (Bradow and Davidonis, 2000).

Earlier, cotton industries were not given much importance to fibre strength compare to other fibre quality parameters. Due to the modernization of textile industry through increased automation of high speed spinning, fibre strength stands first in order of preference followed by length, for making cotton quality to be comparable and competitive with the man made fibre. There is an urgent need to develop cotton varieties or hybrids for high fibre strength (more than $25 \mathrm{~g} /$ tex) because the fibre strength in present day Indian cultivars, especially upland and desicotton (Indian origin cotton, G. arboreum and G. herbaceum) is between 15 to $22 \mathrm{~g}$ per tex. Screening germplasm followed by integration of high fibre quality with high lint yield is the breeding strategy to be followed. The information on the gene effects for various yield and quality characters are needed for formulation an efficient breeding programme to achieve desired genetic improvement in cotton. The present investigation has been conducted to investigate the gene effects in three single crosses of upland cotton for yield and fibre quality parameters.

\section{Materials and methods}

The experimental material comprised of three parents, their respective $\mathrm{F} 1$ hybrids and segregating populations (F2) and back cross populations to each parent (BC1 and BC2). The research trial was laid put in Randomized Block Design (RBD) with three replication at Tamil Nadu Ag- 
ricultural University, Coimbatore in Kharif (rainy) $2007-$ 2008. Parents and F1's in two rows and F2's and back cross populations in four rows of $6 \mathrm{~m}$ length were sown in each replication. The selected field was irrigated, black soil and the normal production practices were followed with spacing of $75 \mathrm{~cm}$ between rows and $60 \mathrm{~cm}$ between plants. Data on five random plants from each replication of parents, F1's and backcross populations and fifteen plants per replication in $\mathrm{F} 2$ generation were recorded on both quality and quantitative characters as mentioned in Tab. 1 and 2 .

Tab. 1. Gene effects and type of epistasis (gene interaction) for lint yield and their components characters in upland cotton

\begin{tabular}{|c|c|c|c|c|c|c|c|}
\hline \multirow{2}{*}{ Characters } & \multicolumn{6}{|c|}{ Gene effects } & \multirow{3}{*}{$\begin{array}{l}\text { Type of } \\
\text { epistasis }\end{array}$} \\
\hline & $\mathrm{m}$ & d & h & $\mathrm{i}$ & j & 1 & \\
\hline \multicolumn{7}{|c|}{ KC2 $\times$ MCU5 } & \\
\hline Symbodia per plant & $21.82^{* *}$ & -2.47 & -2.62 & -1.29 & -0.73 & -8.44 & $\begin{array}{c}\text { Complem- } \\
\text { entary } \\
\text { epistasis }\end{array}$ \\
\hline Number of bolls & $22.20^{* *}$ & -2.67 & 10.73 & NS & NS & NS & - \\
\hline Boll weight & $3.71^{* *}$ & $-0.84^{* *}$ & 0.97 & 0.65 & -0.50 & -0.39 & $\begin{array}{c}\text { Duplicate } \\
\text { epistasis }\end{array}$ \\
\hline Single plant yield & $78.91^{* *}$ & -31.08 & 77.45 & 58.60 & -18.25 & -71.60 & $\begin{array}{c}\text { Duplicate } \\
\text { epistasis }\end{array}$ \\
\hline Seed index & $9.73^{* *}$ & -1.01 & -0.74 & NS & NS & NS & - \\
\hline Lint index & $5.80^{* *}$ & -1.22 & $-2.66^{* *}$ & -2.61 & $-0.99^{* *}$ & $3.77^{* *}$ & $\begin{array}{c}\text { Duplicate } \\
\text { epistasis }\end{array}$ \\
\hline Ginning outturn & $37.91^{* *}$ & -3.13 & $-11.89^{*}$ & $-12.86^{* *}$ & $-4.42^{* *}$ & $17.16^{* *}$ & $\begin{array}{c}\text { Duplicate } \\
\text { epistasis }\end{array}$ \\
\hline \multicolumn{8}{|c|}{$\mathrm{KC} 2 \times \mathrm{MCU} 12$} \\
\hline Symbodia per plant & $18.80^{* *}$ & 1.73 & 5.07 & NS & NS & NS & \\
\hline Number of bolls & $20.04^{* *}$ & -3.80 & 10.62 & 8.76 & -1.53 & -5.16 & $\begin{array}{c}\text { Duplicate } \\
\text { epistasis }\end{array}$ \\
\hline Boll weight & $3.93^{* *}$ & 0.42 & $1.84^{* *}$ & $1.47^{*}$ & 0.79 & $-2.66^{*}$ & $\begin{array}{c}\text { Duplicate } \\
\text { epistasis }\end{array}$ \\
\hline Single plant yield & $73.55^{* *}$ & -7.46 & $98.68^{* *}$ & $84.62^{*}$ & 9.65 & -94.70 & $\begin{array}{c}\text { Duplicate } \\
\text { epistasis }\end{array}$ \\
\hline Seed index & $9.06^{* *}$ & 0.48 & $4.39^{*}$ & $4.21^{*}$ & 0.98 & $-5.96^{*}$ & $\begin{array}{c}\text { Duplicate } \\
\text { epistasis }\end{array}$ \\
\hline Lint index & $5.65^{* *}$ & 0.54 & 1.43 & 1.18 & 0.88 & -2.11 & $\begin{array}{c}\text { Duplicate } \\
\text { epistasis }\end{array}$ \\
\hline Ginning outturn & $38.48^{* *}$ & 1.13 & -5.57 & NS & NS & NS & - \\
\hline \multicolumn{8}{|c|}{ MCU5 $\times$ MCU12 } \\
\hline $\begin{array}{c}\text { Symbodia per } \\
\text { plant. } K=\end{array}$ & $20.00^{* *}$ & 0.80 & 1.07 & NS & NS & NS & \\
\hline Number of bolls & $21.02^{* *}$ & -2.13 & 10.04 & 11.38 & -1.27 & -15.11 & $\begin{array}{c}\text { Duplicate } \\
\text { epistasis }\end{array}$ \\
\hline Single plant yield & $84.36^{* *}$ & -6.05 & $101.89^{* *}$ & 92.80 & -1.77 & $-112.95^{*}$ & $\begin{array}{c}\text { Duplicate } \\
\text { epistasis }\end{array}$ \\
\hline Seed index & $11.05^{* *}$ & $-0.74^{*}$ & -3.05 & -2.96 & -1.20 & 3.70 & $\begin{array}{c}\text { Duplicate } \\
\text { epistasis }\end{array}$ \\
\hline Lint index & $5.45^{* *}$ & -0.15 & 2.75 & $2.50^{*}$ & -0.03 & $-3.08^{*}$ & $\begin{array}{c}\text { Duplicate } \\
\text { epistasis }\end{array}$ \\
\hline Ginning outturn & $33.52^{* *}$ & 1.08 & $15.47^{*}$ & $14.27^{*}$ & 2.59 & $-18.22^{* *}$ & $\begin{array}{c}\text { Duplicate } \\
\text { epistasis }\end{array}$ \\
\hline
\end{tabular}

Where, $\mathrm{m}=$ mean, $\mathrm{d}$ = additive, $\mathrm{h}=$ dominance, $\mathrm{i}=$ additive $\mathrm{x}$ additive, $\mathrm{j}=$ additive $\mathrm{x}$ dominance, $\mathrm{l}=$ dominance $\times$ dominance NS $=$ Non Significant,${ }^{*}=$ significant at the 0.05 probability level, ${ }^{* *}=$ significant at the 0.01 probability level

Crosses were showing significant variation among generations in randomized block design were subjected to generation mean analysis for six parameters according to
Mather and Jinks (1971). The scaling test was to detect the presence of epitasis (Mather, 1949).

\section{Results and discussion}

Gene effects in six parameter model revealed that mean values were highly significant for all the characters in all the crosses (Tab. 1 and 2). The cross ' $\mathrm{KC} 2 \times \mathrm{MCU}$ 5 ' showed significant additive gene effects (d) for boll weight, single plant yield, lint index, ginning outturn, 2.5 percent span length, fineness and elongation percentage. The crosses 'KC2 x MCU12' for 2.5 percent span length, uniformity ratio and elongation percentage, and 'MCU5 $x$ MCU12' for seed index, bundle strength, fineness, uniformity ratio and elongation percentage showed significant additive gene effects (d), indicating that additive gene action was operative for the control of these traits in respective crosses. For improving above characters, pedigree method will be useful for selection of segregate for finding superior genotypes.

Tab. 2. Gene effects and type of epistasis (gene interaction) for fibre quality characters

\begin{tabular}{|c|c|c|c|c|c|c|c|}
\hline \multirow{2}{*}{ Characters } & \multicolumn{6}{|c|}{ Gene effects } & \multirow{3}{*}{ Type of epistasis } \\
\hline & $\mathrm{m}$ & d & $\mathrm{h}$ & $\mathrm{i}$ & j & 1 & \\
\hline \multicolumn{7}{|c|}{$\mathrm{KC} 2 \times \mathrm{MCU} 5$} & \\
\hline $2.5 \%$ span length & $29.63^{* *}$ & $-1.86^{* *}$ & 0.84 & 1.03 & 1.86 & -3.66 & Duplicate epistasis \\
\hline Bundle strength & $22.37^{* *}$ & -0.24 & $-2.92^{*}$ & $-3.50^{*}$ & 0.84 & 1.96 & Duplicate epistasis \\
\hline Fineness & $4.11^{9 *}$ & $-0.21^{*}$ & $-1.61^{* *}$ & $-1.66^{* *}$ & $-0.39^{* *}$ & $1.47^{*}$ & Duplicate epistasis \\
\hline Uniformity ratio & $48.24^{* *}$ & -1.13 & -4.38 & $-4.04^{*}$ & $-4.53^{*}$ & 4.31 & Duplicate epistasis \\
\hline $\begin{array}{l}\text { Elongation } \\
\text { percentage }\end{array}$ & $6.47^{* *}$ & $0.26^{*}$ & 0.65 & 1.16 & -0.28 & -0.90 & Duplicate epistasis \\
\hline \multicolumn{8}{|c|}{$\mathrm{KC} 2 \times \mathrm{MCU} 12$} \\
\hline $2.5 \%$ span length & $28.42^{* *}$ & $2.01^{* *}$ & $13.24^{* *}$ & $11.22^{* *}$ & $3.43^{* *}$ & $-23.98^{* *}$ & Duplicate epistasis \\
\hline Bundle strength & $20.76^{* *}$ & 0.01 & $2.71^{*}$ & $2.64^{*}$ & 0.71 & $-6.43^{* *}$ & Duplicate epistasis \\
\hline Fineness & $4.11^{9 *}$ & 0.04 & $-2.45^{* *}$ & $-2.41^{* *}$ & 0.08 & $3.67^{* *}$ & Duplicate epistasis \\
\hline Uniformity ratio & $49.26^{* *}$ & $-2.33^{* *}$ & $-9.72^{* *}$ & $-8.22^{* *}$ & $-4.10^{* *}$ & $16.69^{* *}$ & Duplicate epistasis \\
\hline $\begin{array}{l}\text { Elongation } \\
\text { percentage }\end{array}$ & $7.02^{* *}$ & $-1.01^{* *}$ & 0.07 & 0.14 & $-1.03^{* *}$ & 1.91 & $\begin{array}{l}\text { Complementary } \\
\text { epistasis }\end{array}$ \\
\hline \multicolumn{8}{|c|}{ MCU5 $\times$ MCU12 } \\
\hline $2.5 \%$ span length & $30.57^{* *}$ & 0.73 & $7.76^{* *}$ & $7.11^{* *}$ & $-1.58^{* *}$ & $-12.17^{* *}$ & Duplicate epistasis \\
\hline Bundle strength & $20.82^{* *}$ & $2.94^{* *}$ & $4.88^{* *}$ & $4.88^{* *}$ & $2.57^{* *}$ & $-6.98^{* *}$ & Duplicate epistasis \\
\hline Fineness & $4.07^{* *}$ & $-0.53^{* *}$ & -0.69 & $-0.76^{*}$ & $-0.31^{*}$ & 0.36 & Duplicate epistasis \\
\hline Uniformity ratio & $48.11^{* *}$ & $1.60^{*}$ & $-6.14^{*}$ & -7.38 & $3.23^{* *}$ & $7.58^{*}$ & Duplicate epistasis \\
\hline $\begin{array}{l}\text { Elongation } \\
\text { percentage }\end{array}$ & $6.96^{* *}$ & $0.65^{*}$ & -0.04 & 0.02 & 1.17 & 0.24 & Duplicate epistasis \\
\hline
\end{tabular}

Where, $\mathrm{m}=$ mean, $\mathrm{d}$ = additive, $\mathrm{h}=$ dominance, $\mathrm{i}=$ additive $\mathrm{x}$ additive, $\mathrm{j}=$ additive $\mathrm{x}$ dominance, $1=$ dominance $\times$ dominance. NS = Non Significant,${ }^{*}=$ Significant at the 0.05 probability level, ${ }^{* *}=$ Significant at the 0.01 probability level

Pedigree breeding procedure is adequate for achieving the breeding objectives for improving economic traits for the crosses which show additive gene variance. Pedigree breeding for improving genotypes was suggested by Patel and Bandaya (1993) for seed cotton yield, Wang and Pan 
452

(1991) for boll weight, seed index and 2.5 percent span length, Meredith and Bridge (1972) for fiber fineness in cotton.

Dominance gene action was significantly operative in the cross 'KC2 x MW5' for single plant yield, lint index, ginning outturn, bundle strength, fineness and uniformity ratio in ' $\mathrm{KC} 2 \mathrm{x}$ MCU12' for boll weight, single plant yield, seed index, 2.5 percent span length, bundle strength, fineness and uniformity ratio: and in 'MUC5 x MUC12' for single plant yield lint index, ginning outturn, 2.5 percent span length, bundle strength and uniformity ratio. The relative magnitude of additive (d) and dominance (h) gene effects indicated that bundle strength and single plant yield were predominantly under the control of additive and dominance gene action gene action, respectively in the cross 'MW5 x MW12'. Dominance gene action was reported for plant height and number of bolls per plant (Arumugam Pillai and Amirthadevarathirnam, 1997; Sandhu et al., 1992); seed cotton yield per plant (Despande et al., 1988; Sandhu et al., 1992; Patel and Badaya, 1995; Kumaresan et al., 2000); fibre fineness by Subrahmanyam et al. (1989) and plant height, seed index, ginning outturn and elongation percentage by Saravanan (2004).

The predominance of both additive and dominance gene effects was also reported by Dhorajia et al. (1995) and Wang and Pan (1991) for number of bolls per plant, Nadarajan et al. (1999) for lint index, seed index, ginning outturn. Wang and Pan (1991), Nadarajan and Sree Rangasmy (1992) and Nadarajan et al. (1999) for 2.5 percent span length, fibre strength, fibre fineness and uniformity ratio. Among the non-allelic gene interaction components, additive $\mathrm{x}$ additive (i) type of gene action was significantly operative for lint index, ginning outturn, bundle strength, fineness and uniformity ratio in cross ' $\mathrm{KC} 2 \mathrm{x} \mathrm{MCU} 12$ ' for boll weight, single plant yield, seed index, 2.5 percent span length, bundle strength, fineness and uniformity ratio and in cross 'MCU $5 \times$ MCU12' for single plant yield, lint index, ginning outturn, 2.5 percent span length, bundle strength and fineness showed additives $\mathrm{x}$ additive (i) type of gene action.

The additive $x$ dominance $(j)$ type of gene action was significantly operate for boll weight, lint index, ginning outturn, fineness and uniformity ratio in cross ' $\mathrm{KC} 2 \mathrm{x}$ MCU12' and for seed index, ginning outturn, 2.5 percent span length, bundle strength, fineness and uniformity ratio in cross 'MCU5 x MCU12'. Dominance x Dominance (1) type of gene action was significantly operate for lint index, ginning outturn and fineness, in cross KC2 x MCU5: for boll weight, seed index, 2.5 percent span length, bundle strength, fineness and uniformity ratio in cross MCU5 $\mathrm{x}$ MCU12.

In order to exploit the presence of both additive $\mathrm{x}$ dominance gene in a population/ cross, the superior phenotypes selected on the basis of their progeny performance can be recombined and the products evaluated to form on improved population base for another cycle of selection. This cycle process gradually tends to change the gene frequency of desired alleles in the population. In fact, the best way to capitalize advantages of both addition and over dominance effects is perhaps to resort among selected families. If is thus intuitively obvious that mild inbreeding will strengthen the correspondence between the genotype and the phenotype thus promoting the prospects of selection (Sharma, 1994).

Duplicate type epitasis was involved in the development of all the crosses in majority of the characters. In general, the duplicate epitasis was found to be predominant to complementary epitasis. There fore in order to exploit the presence of interaction effects mainly dominance $x$ dominance and additive $\mathrm{x}$ dominance type, recurrent selection techniques may be useful as reported by Nadarajan and Rangasamy (1991) for lint yield. Predominance of duplicate was reported by Thombre et al. (1987) for seed cotton yield per plant. In contrast, predominance of complementary epitasis was reported by Taware and Patil (1994) for plant height, Arumugam Pillai and Amitthadevarathinam (1997) for number of sympodia per plant and seed cotton yield per plant, Jashi et al. (1961) and Taware and Patil (1994) for number of bolls. Additive component of variation (D) was reported by May and Green (1994), Hendawy et al. (1999), Ahmad et al. (2003), Iqbal et al. (2003), Haq and Azhar (2004), Basal and Turgut (2005), Muhammad et al. (2008) for all fibre quality characters.

For quantitative and quality characters duplicate epistasis was predominant in most of the crosses. Therefore exploiting these characters by recurrent selection may be utilized as suitable breeding technique. Some of the characters controlled by additive gene action were also observed. For exploiting these characters pedigree selection may also be suitable. Other characters for which additive and dominance gene action was observed reciprocal breeding technique may be appropriate.

\section{References}

Ahmad S, Iqbal MZ, Hussain A, Sadiq MA, Jabbar A (2003). Gene action and heritability studies in cotton (Gossypium hirsutum L). Online J Biol Sci 4:443-450.

AICCIP report. (2010-11). Annual Group Meeting of All India Coordinated Cotton Improvement Project held on 06-08 April, 2011, HAU, Hisar, Haryana, India.

Arumugam Pillai M, Amirthadevarathinam A (1997). Inheritance of yield and its components in CMS based hybrids of cotton (Gossypium spp.). Indian J Agric Res 31:156-160.

Basal H, Turgut I (2005). Genetic analysis of yield components and fibre strength in upland cotton (Gossypium hirsutum L.). Asian J Plant Sci 27 (4): 207-212.

Dhorajia VK, Pethani KV, Kathiria KB (1995). Genetic architecture of yield and its components in desi cotton (G. arboreum L.). J. Indian Soc. Cott. Improv. 20: 124-128.

Haq I, Azhar FM (2004). Genetic basis of varietal differences 
for seed cotton yield and its components in Gossypium hirsutum L. Int J Agric Biol 5: 904-907.

Hendawy FA, Rady MS, Hamid AM, Ismail RM (1999). Inheritance of fibre traits in some cotton crosses. Egyptian J Agron 21:35-36.

Iqbal M, Chang MA, Iqbal MZ (2003). Breeding behavior effects for yield, its components and fibre quality in intraspecific crosses of cotton (G. hirsutum L.). OnLine J Biol Sci 4:451-459.

Joshi AB, Jain SK, Hukeri PD (1961). Inheritance studies on some components of yield in a cross of two $G$. hirsutum varieties. I. Boll number and boll weight. Indian J Genet 21: 98-105.

Kumaresan D, Ganesan J, Ashok S (2000). Genetic analysis of quantitative characters in cotton $(G$. hirsutum L.). Crop Res 19:481-484.

Mather, K, Jinks JL (1971). Biometrical Genetics - The study of continuous variation. Chapman and Hall Ltd., London.

Mather K (1949). Biometrical genetics, First edition, Methuen: London.

May OL, Green CC (1994). Genetic variation for fibre properties in elite Pee Dee cotton populations. Crop Sci 5:684 690.

Meredith WR, Bridge RR (1972). Heterosis and gene action in cotton (G. hirsutum L.). Crop Sci 12:304-309.

Muhammad AA, Iftikhar AK, Shahid IA, Shiraz A, Shahid N (2008). Genetics of fibre quality traits in cotton (Gossypium hirsutum L.). Aus J Crop Sci 2 (1):10-17.

Nadarajan N, Sree Rangasamy SR (1992). Genetic analysis of certain fibre characteristic in G. hirsutum L. J Indian Soc. Cott Improv 16:15-18.
Nadarajan N, Kumaresan D, Ponnusamy K, Azhaguvel P (1999). Genetic analysis of fibre quality characters in upland cotton (G. hirsutum L.) In: International seminar on "Cotton and its utilization in the $21^{\text {st }}$ century". Dec. 10-12, CIRCOT, Mumbai. p. 43.

Patel GS, Badaya SN (1993). Gene effects for yield and yield contributing characters in upland cotton ( $G$. hirsutum L.). J Indian Soc Cott Improv 18:103-106.

Sandhu BS, Gill MS, Mittal VP (1992). Genetic architecture of Gossypium arboreum. Indian J Genet 52:257-260.

Saravanan NA (2004). Genetical and cytogenetical investigation on inter and intra specific crosses of Gossypium spp for jassid resistance and yield. TNAU, Coimbatore, India, PhD Diss.

Sharma JR (1994). Principles and practices of plant breeding. P.449. Tata Mccraw, Hill publishing company Ltd New Delhi.

Subrahmanyam Y, Mehta NP, Patel J, Bhalod MC, Iyer JK, Munshi VG (1989). Genetic studies on fibre fineness in Asiatic cotton. J Indian Soc Cott Improv 14:153-158.

Taware SP, Patil VP (1994). Genetic analysis of pink bollworm resistance and other quantitative characters in cotton. Indian J. Genet. 54:137-141.

Thombre MV, Pathade SV, Patil FB (1987). Genetic analysis of boll number, boll weight and seed cotton yield. J Maharashtra Agric Univ 12:306-308.

Wang XD, Pan JJ (1991). Genetic analysis of heterosis and inbreeding depression in upland cotton. Acta Agron Sinica 17:18-23. 